\title{
The Effectiveness of Online Education during Covid 19 Pandemic-A Comparative Analysis between the Perceptions of Academic Students and High School Students from Romania
}

\author{
Gina Ionela Butnaru ${ }^{1}$, Valentin Niță ${ }^{1}$, Alexandru Anichiti ${ }^{2, *}$ and Geanina Brînză ${ }^{2}$ \\ 1 Department of Management, Marketing and Business Administration, Faculty of Economics and Business \\ Administration, Alexandru Ioan Cuza University of Iași, 700505 Iași, Romania; gina.butnaru@uaic.ro (G.I.B.); \\ valnit@uaic.ro (V.N.) \\ 2 Department of Business Administration, Stefan cel Mare University of Suceava, 13 University Street, \\ 720229 Suceava, Romania; brinza.geanina@gmail.com \\ * Correspondence: alexandru.anichiti@usm.ro
}

Citation: Butnaru, G.I.; Niță, V.; Anichiti, A.; Brînză, G. The Effectiveness of Online Education during Covid 19 Pandemic-A Comparative Analysis between the Perceptions of Academic Students and High School Students from Romania. Sustainability 2021, 13, 5311 https://doi.org/10.3390/su13095311

Academic Editors: Miltiadis D. Lytras, Abdulrahman Housawi and Basim Alsaywid

Received: 9 April 2021

Accepted: 4 May 2021

Published: 10 May 2021

Publisher's Note: MDPI stays neutral with regard to jurisdictional claims in published maps and institutional affiliations.

Copyright: (c) 2021 by the authors. Licensee MDPI, Basel, Switzerland. This article is an open access article distributed under the terms and conditions of the Creative Commons Attribution (CC BY) license (https:// creativecommons.org/licenses/by/ $4.0 /)$.

\begin{abstract}
The COVID-19 pandemic has disrupted normal activities such as going to school, moving education online. Based on data gathered through a survey $(\mathrm{N}=784)$, this paper analyses students perceptions regarding the effectiveness of online education in a period when this type of education is the only available option. Although several studies suggest that online education can be as effective as traditional education which requires attendance, few studies have focused on learner satisfaction with online instruction, particularly in the transition to online learning from traditional approaches. The results indicate that students react differently to online education, and their reaction is based on their proficiency in using online tools, their ability to technically access online courses, and the instructors' manner in conducting learning activities.
\end{abstract}

Keywords: the COVID-19 pandemic; online education; online courses; the satisfaction of students; higher education

\section{Introduction}

In order to prevent the spread of the SARS-COV2 virus, Romania developed a strategy to prevent and control the situation, it includes: the cancellation or closure of flights, the closure of restaurants and hotels, and mandatory quarantine for infected people or people who are suspected to be infected. Thus, institutions including schools, high schools and universities have temporarily suspended their traditional courses, migrating to a model of online education.

The SARS-CoV2 virus has threatened the activity of high schools, colleges and universities, which is why the issue of whether or not to continue teaching and learning has been raised, provided that the health of students and of education staff is protected. Educational institutions preferred to close traditional (face-to-face) teaching activities, including laboratories, and transferred teaching activities to the online environment in order to prevent the spread of the virus. Forcibly moving educational activity to the online environment allows for flexibility in teaching and learning because courses are easily accessed. Despite the crisis, courses were transferred online at an astonishing and unprecedented speed [1-3].

As a distinctive feature, this study aims to compare the perceptions of university students (both undergraduate and postgraduate) and of high school students regarding the effectiveness of online courses. Although the study of university students' / high school students' perceptions regarding the effectiveness of online courses has been an intensely studied topic by authors such as Bentley [4], Bali and Liu [5], and Platt, Raille and Yu [6], their studies used a scenario in which there was the possibility of attending both online courses and courses in the study rooms (face to face with university students/high school 
students). Therefore, this research analyses the perceptions of undergraduate and postgraduate students and of high school students in a time when there is only the possibility of online courses, in a state of emergency caused by the COVID-19 pandemic.

In order to study the perceptions of undergraduate and postgraduate students and of high school students regarding the effectiveness of online courses, we used a survey applied to undergraduate and postgraduate students from Alexandru Ioan Cuza University of Iași and students from Virgil Madgearu Economic Technological High School of Iași, between 25 March and 30 April 2020. The survey included questions with Likert-type scale responses, with control questions regarding age, gender, education level, access to the use of technologies, etc. A total of 784 responses were received in this survey.

Therefore, this paper is structured in the following sections: introduction, literature analysis and development of research hypotheses, research methodology, results, discussions, and conclusions.

\section{Literature Analysis}

\subsection{Advantages vs. Disadvantages of Online Education}

The impact of the COVID-19 pandemic has led to the temporary interruption of educational activities in the classroom. University students and high school students in their final years are in an unprecedented situation, which does not allow for a clear perspective of the future. The length of the pandemic and its effects on daily life, costs and other financial issues can directly affect the continuation of the education of university students and high school students. The vulnerability caused by the disturbances in the academic space is worrying. The situation of both undergraduate and postgraduate students has generated unfavorable conditions, such as the necessity to drop out of education. A feeling of exclusion was created by the pandemic situation, outlining an image of inequity in the academic education system [7-9].

Online education has the potential to transform the education system by expanding educational opportunities, transforming student populations and encouraging the development of new pedagogical methods $[6,10,11]$, making the learning process more reliable, more efficient, and less stressful for both instructors and students. Although there are studies suggesting that online and traditional education are comparable in terms of learning outcomes, it is also admitted that online learning is perceived as lacking in interactivity compared with classroom learning [5,12]. However, in a study including 156 students, Fortune, Spielman and Pangelinan [13] concluded that there was no statistically significant difference in learning preferences between students attending online courses and students attending courses in person.

The effectiveness of online education has shown a number of advantages due to increased flexibility and learning opportunities: easy access to experts, exposure to educational environments, a wide range of types of courses, and joining student communities. There are also several disadvantages of online education, such as: internet browsing issues, computer compatibility, or technical issues [14,15].

At the beginning of the COVID-19 pandemic, students had to reorganize their daily schedule to adapt to a situation of isolation. Those studying abroad had to go back home, but, at the same time, many of them were blocked due to the closure of airports and borders. The lack of socialization affected students and their socio-emotional balance suffered, especially in young people with pre-existing problems of this nature. Students claimed that main the effects of isolation were anxiety and depression [16].

Therefore, this study proposes to test the following hypotheses:

Hypothesis 1 (H1). The perception of the effectiveness of face-to-face courses will influence students' desire for physical class attendance.

Hypothesis 2 (H2). The perception of the effectiveness of face-to-face courses will negatively influence the perception of the effectiveness of online courses. 


\subsection{Premises of a Good Experience with Online Education}

A significant relationship has been reported between the degree to which students feel comfortable using the internet and their general feeling of satisfaction with the online experience [17].

Research has proven that advances regarding information technology and the evolution of computers positively affect the approach of university/high school students on learning in contemporary educational environments [18,19]. Mobile devices and easy internet access have changed the paradigm of communication in the context of the education system. Social networks used in everyday life can bring about changes in teaching methods and generate improvements by stimulating and involving students in the learning process $[20,21]$.

In the context of the COVID-19 pandemic, the sudden and forced transition from traditional education to online education has had negative effects on the preparation of university students and high school students [22,23]; these effects are generated by problems with access to technology and internet networks, and by the diminished quality of teaching [24].

In Romania, during the period of isolation, parents had to ensure students' access and participation in online learning activities organized by their educational institutions. The technology required to participate in online courses is as follows: laptop/smart phone/tablet and internet access. This technology may belong to the students' families or educational institutions. The damages caused to loaned technical and communication equipment falls entirely on the parents or legal guardians. The access to platforms, digital learning resources and virtual libraries is free [24,25].

According to Kebritchi et al. [26], in order to support students in online education, prior training in technical skills is necessary for the efficient use of computers and the internet. Other factors are important as well, such as: the students' perception and attitude towards the internet, their level of knowledge of English, and how the students manage their time. The success of online education is given by the dimensions suggested by Hung et al. [27]: learning motivation, self-directed learning, computer and internet quality, effectiveness of online communication, and student control.

Therefore, this study proposes to test the following hypotheses:

Hypothesis 3 (H3). The students who do not possess the technology needed for easy access to online courses will perceive them as ineffective compared with the students who possess the technology.

Hypothesis 4 (H4). The students who can browse the internet easily will perceive the effectiveness of online courses differently compared with the other students.

\subsection{Adapting Educational Institutions to Online Education vs. the Effect on the Trust of University Students and High School Students}

Educational institutions have had to adapt to the restrictions created by the COVID-19 pandemic $[28,29]$. A series of applications, platforms and educational resources have been launched to support high school and university students, teachers and professors, parents, educational institutions and school managers, with the aim of facilitating the study process of high school/university students, providing social support and facilitating interaction during the closure of educational institutions [3,30,31].

Online courses were initially designed in the format of a teacher/professor teaching material in a classroom, transmitted and stored with the help of technology, so that the information could be accessed later and repeatedly by students. Students seem to appreciate this format because they have the possibility of easy access to the information. However, undergraduate students tend to be more conservative, which is why they do not appreciate the format of online courses, compared with postgraduate students who are more open to modern work methods in the educational environment, and prefer participatory methods and direct interaction within the university $[32,33]$. Online courses require more discipline 
from the students. Higher success rates for online courses can be seen in postgraduate students due to their maturity, while undergraduate students are more disinterested in this format, and high school students are much less inclined to online courses [10]. High school and university students feel attached to the teachers/professors and/or schoolmates with whom they work. Interaction and social relationships give individuals a sense of security, trust and love, and these aspects can generate significant success for the educational process $[34,35]$. High aspirations, care and positive attitude towards learning, motivation and encouragement of group members, professors for university students, and teachers for high school students, can contribute to positive academic results. University students and high school students who do not receive significant moral support from their family compensate with the moral and social support provided by teaching staff, which can have significant positive effects on school results and general success [36,37].

The students who appreciate participation in traditional classroom courses consider it is important to interact with academia for face-to-face meetings with professors and schoolmates, and for immediate feedback generated by the stated circumstances [38,39]. High school students' perception in the pre-academic environment is similar. The challenge of transferring contents from a traditional teaching format to an online format generates certain problems, and there are differences in perception [26]. Thus, students consider online courses ineffective due to the effects generated by distance learning: limited interaction with the school environment and schoolmates, and increased interaction with technology $[40,41]$. The teaching staff faces problems regarding content delivery and lower student interest due to the absence of face-to-face meetings, lower control over student groups, and a blockage in the ability to correct these situations [26,42].

Therefore, this study proposes to test the following hypotheses:

Hypothesis 5 (H5). Students' desire for physical class attendance will generate the perception of ineffectiveness of online courses.

Hypothesis 6 (H6). The capacity of educational institutions to manage online courses will have a positive effect on the students' perception of the effectiveness of online courses.

\subsection{Training of the Teaching Staff Regarding Online Education vs. the Effect on the Trust of University Students and High School Students}

The COVID-19 pandemic has caused unprecedented damage to the education system, especially in educational institutions, and in particular to teaching staff-the most critical resource of any educational institution, which have to face financial, physical, and mental challenges $[43,44]$.

Teaching staff use teaching methods virtually, which are not affected by the additional demands generated by the context of the coronavirus pandemic. Every academic or preacademic educational institution have the necessary tools for the formation of a virtual class, as an extension of the real class. However, the ability of the teaching staff to adapt to the new requirements is greatly affected by the formation of the working skills with new technologies. The teaching staff who had access to distance learning courses and digital resources have a lower risk of maladaptation to the difficulties generated by online courses and have the confidence to continue teaching according to the new conditions. In the context generated by the COVID-19 pandemic, the simplest option of the teaching staff is to teach their classes by video, either live or digitally transmitted $[8,30,31]$.

It is essential to ensure the continuity of teaching in the online environment, so the teaching staff must build their own skills to be able to work in virtual environments that are of high quality and technological complexity, for which special training is not necessarily required $[16,45]$.

Traditional teaching used body language, facial expressions, and the teacher's voice as important learning tools. The transition to online teaching courses created restrictions on the above and highlighted the importance of emphasis in teachers' voice and reducing 
the amount of speech presented to high school students on key knowledge, using a smaller number of words [46].

Teaching staff must take into account three elements when designing the content for online courses: theoretical materials, pedagogy, and technology. If these elements are perfectly combined, they ensure efficient and high-quality teaching [11,47]. Transmission of content with the help of technology is much more efficient if the teaching staff create collaborative, reflective activities and draw clear criteria regarding evaluation-in online education, evaluation is carried out with the help of digital technologies [48]. According to Kebritchi et al. [26] and Duncan [49], the transition from traditional courses to online courses requires content redesign strategies to integrate technology. Redesigning courses lowers costs and can increase students' memorization speed. Course redesign strategies involve interactive learning in the online environment with the support of multimedia tools.

Cross [50] and Song, Kim and Luo [51] consider that the teacher-student relationship is based on a series of experiences and expectations. Students appreciate teachers who provide quick, permanent and open feedback, who provide prompt responses, who know the curricula content and the teaching methods in detail, who constantly assist the students in the preparation stages, and who have a positive behavior in the instructional/educational act. Students want their teachers to have initiative, to take the first step in the educational activities, to prepare the students for the online classes, and to have a positive behavior, as the support and modelling offered by the teachers contribute to their subsequent success. Mather and Sarkans [38] also identified factors that can improve the learning process and student satisfaction, such as: promptness of teachers'/professors' responses, clarity of tasks, and easy access to the content. In online learning activities, students appreciate flexibility and convenience. Cross [50] concludes that all the teaching staff, regardless of the level of education (academic or pre-academic), should pay more attention to students' perceptions and consider them in instructional/educational activities.

Educational institutions have adopted educational platforms that have the advantage of collecting digital teaching resources, whose availability and quality are particularly important; these are alternatives to online courses conducted by videoconference [8,52].

Teaching staff were trained within projects aiming to capitalize on new technologies in teaching-learning activities. The development of the digital skills of the teaching staff is a priority for the education system. Training through courses or projects for online education aims to use online tools in distance learning activities with university students and / or high school students $[53,54]$.

Isolation has made the situation of education in Romania uncertain and uncomfortable, the lack of clear, coherent and specific measures to continue instructive/educational activities has created stress and anxiety for most teaching staff, high school students and parents/legal guardians $[43,55,56]$.Teachers were forced to identify new methods to offer all high school students the opportunity to participate directly/indirectly in online courses, which caused them to be more lenient and more understanding of students' personal situations. The materials sent by the teachers through the learning platforms, the work tasks sent to the high school students in a less favorable situation, the exclusively online communication, and the lower quality of the pedagogical act, in addition to the students lack of interest, lowered the teachers' expectations regarding the quality of the topics and contents to be prepared for classes $[43,57]$.

Therefore, this study proposes to test the following hypotheses:

Hypothesis 7 (H7). The capacity of the teaching staff to be more lenient will have a positive effect on the perception of the effectiveness of online courses.

Hypothesis 8 (H8). The perception of the ability of teaching staff to manage online courses will have a positive effect on the perception of the adaptation of the educational institution to online education. 
Figure 1 shows a conceptualization of the model regarding the effectiveness of online courses:

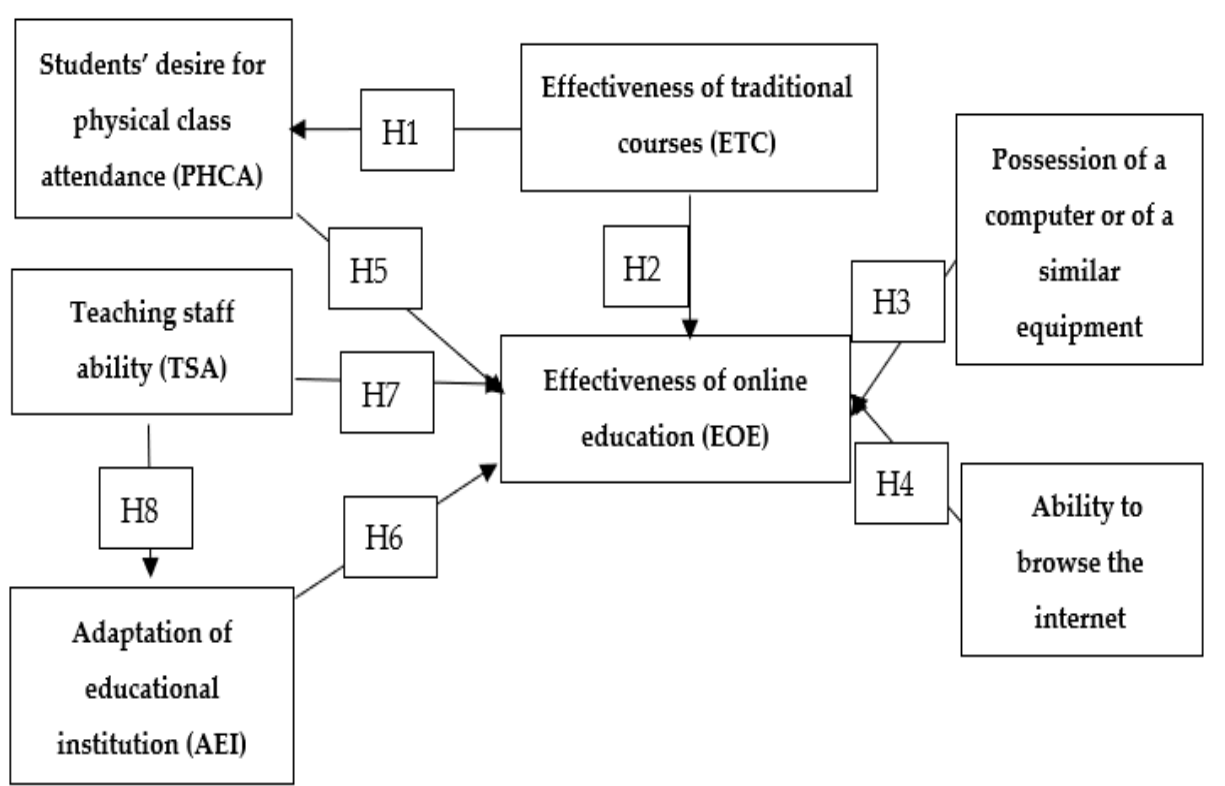

Figure 1. Conceptual model regarding the effectiveness of online courses.

As such, this study used the variables presented in Table 1.

Table 1. List of variables used in this study.

\begin{tabular}{|c|c|c|}
\hline Variable & Description & Type of Variable \\
\hline PHCA & Students' desire for physical class attendance. & Construct \\
\hline ETC & $\begin{array}{l}\text { Perceptions of university students and of high school students regarding the } \\
\text { effectiveness of face-to-face courses in the classroom. }\end{array}$ & Construct \\
\hline EOE & $\begin{array}{l}\text { Perceptions of university students and of high school students regarding the } \\
\text { effectiveness of online courses. }\end{array}$ & Construct \\
\hline AEI & $\begin{array}{l}\text { Perceptions of university students and of high school students regarding the } \\
\text { adaptation of educational institutions to online education requirements. }\end{array}$ & Construct \\
\hline TSA & $\begin{array}{l}\text { Perceptions of university students and of high school students regarding the } \\
\text { adaptation of teaching staff to the new requirements of online education. }\end{array}$ & Construct \\
\hline Gender & $\begin{array}{l}\text { A categorical variable, which takes the value } 0 \text { when the respondent's gender is } \\
\text { male and the value } 1 \text { when the gender is female. }\end{array}$ & Categorical \\
\hline Age & Represents the respondents' age. & Numerical \\
\hline $\begin{array}{l}\text { Ability to browse } \\
\text { the internet }\end{array}$ & $\begin{array}{l}\text { The respondents who "strongly agreed" or "agreed" with the statement "I am able } \\
\text { to easily access the internet in accordance with the educational interests" were } \\
\text { classified as respondents who had the capacity to use technologies that are able to } \\
\text { access online courses and they were encoded with the value } 1 \text {. Those who } \\
\text { expressed "total disagreement" or "disagreement" with the statement from above } \\
\text { were classified as university/high school students who had no technical } \\
\text { knowledge required to access and participate in the online courses, and were } \\
\text { encoded with the value } 0 .\end{array}$ & $\begin{array}{l}\text { Dummy/ } \\
\text { binary }\end{array}$ \\
\hline $\begin{array}{l}\text { Possession of a } \\
\text { computer or of } \\
\text { similar equipment }\end{array}$ & $\begin{array}{l}\text { The respondents who "strongly agreed" or "agreed" with the statement "I have a } \\
\text { computer which allows me to participate easily in online courses" were encoded with } \\
\text { the value } 1 \text {, and those who expressed "total disagreement" or "disagreement" } \\
\text { with the statement from above were encoded with the value } 0 \text {. }\end{array}$ & $\begin{array}{l}\text { Dummy/ } \\
\text { binary }\end{array}$ \\
\hline
\end{tabular}




\section{Materials and Methods}

\subsection{Description of the Research Method}

The current study included 784 participants: 575 women (74.34\%), and 209 men (26.66\%). The average age of the participants was 20.30 years. The participants in this study $(n=784)$ were undergraduate, postgraduate, and high school students. The recruitment of participants was performed through an e-mail sent to university students and high school students. The participants were instructed to take into account their general experience regarding education and online courses when answering the questions, instead of assessing the quality of the courses they attended online. Thus, the interested students followed a link to an online survey conducted through Google Forms, where they answered questions aimed at measuring their perception of the effectiveness of online education in general, and in the situation caused by the COVID-19 pandemic in particular.

\subsection{The Sample}

Although there is no general method for determining the optimal sample size, researchers have proposed recommendations and guidelines regarding appropriate sample sizes when performing a factor analysis. Field [58] recommended at least 10 subjects per variable to reduce sampling errors. Comrey and Lee [59] provided the following recommendations for appropriate sample sizes: $100=$ poor, $200=$ ok, $300=$ good, $500=$ very good, 1000 or more $=$ excellent.

In the present research, the population analyzed included 784 students participating in online education from Alexandru Ioan Cuza University of Iași and Virgil Madgearu Technological Economic High School of Iași. The population was selected randomly. All participants had the opportunity to ask questions or communicate their concerns about the survey.

\subsection{Work Stages}

The survey was evaluated in two stages, as follows:

(1) Face validity: we made sure that the respondents understood the questions. In this respect, there were no misleading questions using multiple negations or unclear formulations;

(2) Construction validity testing: we used an analysis of exploratory factors and reliability, i.e., Cronbach's alpha tests.

In the first stage, we tested by descriptive statistics and regression analysis the differences between different groups of students (high school students, undergraduate students, postgraduate students, technically challenged and with technical skills, financially capable and financially incapable).

In the second stage, a model of structural equation was tested to analyze the impact of different beliefs on the perception of the effectiveness of online education.

A linear regression analysis was used to test the hypotheses $\mathrm{H} 3$ and $\mathrm{H} 4$, and an SEM model was used to test the hypotheses H1, H2, H5, H6, H7 and H8.

\subsection{Measures}

In this study we used a survey as a data collection tool. We used a five-point Likert scale. Thus, the reliability for each variable used in this study was analyzed by the calculation of Cronbach's alpha. Following the analysis of the exploratory factors, the following scales were constructed, presented in Table 2. 
Table 2. Questions of the survey and outcomes of the factorial exploratory analysis.

\begin{tabular}{|c|c|c|}
\hline Item/Latent Variable & Questions/Observed Variable & Cronbach's Alpha \\
\hline & & 0.8738 \\
\hline PHCA & $\begin{array}{l}\text { PHCA1. I wish to go back to school/university as soon as possible. } \\
\text { PHCA2. I wish to see my teachers/professors again. } \\
\text { PHCA3. I am happier when the courses take place in the } \\
\text { school/academic environment. } \\
\text { PHCA4. I wish to see my schoolmates again. }\end{array}$ & 0.8361 \\
\hline ETC & $\begin{array}{l}\text { ETC1. I feel that the physical attendance of the courses is necessary for an } \\
\text { effective education. } \\
\text { ETC2. I believe that online classes are less motivating than the classes taking } \\
\text { place in a classroom. } \\
\text { ETC3. I want to attend classes in a physical classroom. }\end{array}$ & 0.8458 \\
\hline EOE & $\begin{array}{l}\text { EOE1. I am willing to actively communicate electronically with my } \\
\text { schoolmates and my teachers/professors. } \\
\text { EOE. I could easily adapt to online courses without the direct assistance of the } \\
\text { teaching staff. } \\
\text { EOE3. I am capable of self-discipline and finding time to study at home, too. } \\
\text { EOE4. I believe that a full course can be taught without difficulty through } \\
\text { online programs/ platforms. } \\
\text { EOE5. Online education is efficient during COVID-19 pandemic. }\end{array}$ & 0.8277 \\
\hline AEI & $\begin{array}{l}\text { AEI1. The school/university was prepared to manage the situation of } \\
\text { online teaching. } \\
\text { AEI2. The school/university offered to high school/university students the } \\
\text { required technique (user's guide) to access the online courses. } \\
\text { AEI3. The school/university will be able to guarantee my safety in the future. }\end{array}$ & 0.7151 \\
\hline TSA & $\begin{array}{l}\text { TSA1. The teaching staff were more lenient with the high school/university } \\
\text { students in the process of adaptation to online education. } \\
\text { TSA2. The teaching staff manage to transmit effectively the main ideas and } \\
\text { information to high school/university students through online programs. } \\
\text { TSA3. The online communication with the teaching staff took place } \\
\text { without difficulties. }\end{array}$ & 0.7621 \\
\hline
\end{tabular}

Source: our own calculations based on Stata statistical analysis software.

\section{Results}

\subsection{Results of Regression Equation}

The following multiple regression model was used to test the hypotheses $\mathrm{H} 3$ and H4 of this study, and to identify the factors influencing the perception of the effectiveness of online courses:

$$
Y=\beta_{0}+\beta_{1} X_{1}+\beta_{2} X_{2}+\ldots+\beta_{n} X_{n}+\varepsilon,
$$

In this equation, $\mathrm{Y}$ is the dependent variable and $\mathrm{X}$ is the independent variable. The value of $\beta_{0}$ (which can be negative, positive or zero) is called the intercept, while the value of $\beta_{1}$ is called the "slope" or "regression coefficient".

As described in the introductory section, the statistical analysis was performed using the survey data. The statistical analysis was performed using the statistical program Stata.

The respondents who "strongly agreed" or "agreed" with the statement "I am able to easily access the internet in accordance with the educational interests" were classified as respondents who had the capacity to use the technologies at hand to access the online courses. Those who expressed "total disagreement" or "disagreement" with the statement from above were classified as university/high school students who did not have the required technical knowledge to access and participate in online courses.

The respondents who "strongly agreed" or "agreed" with the statement "I have a computer which allows me to easily participate in online courses" were classified as respondents used to online communication, and those who expressed "total disagreement" or "disagreement" with the statement from above were classified as university/high school 
students who did not have the required technical knowledge to access and participate in online courses.

Table 3 presents the descriptive statistics of the sample included in this study. The current study included 784 participants: 575 women $(74.34 \%)$, and 209 men (26.66\%). The average age of the participants was 20.30 years, with $70.16 \%$ of the respondents between 18 and 25 years old, $23.47 \%$ between 14 and 18 years old, and the remaining 50 respondents being over 25 years old. Regarding the categorization according to the education level, 248 (31.63\%) were high school students, 405 (51.66\%) were undergraduate students, while the remaining 131 (16.71\%) were postgraduate students.

Table 3. Descriptive statistics.

\begin{tabular}{|c|c|c|c|c|}
\hline & & & Number & Percentage $(\%)$ \\
\hline \multirow[b]{2}{*}{ Gender } & \multicolumn{2}{|c|}{ Male } & 209 & 26.66 \\
\hline & \multicolumn{2}{|c|}{ Female } & 575 & 74.34 \\
\hline \multirow{3}{*}{ Age } & \multicolumn{2}{|c|}{$14-18$} & 184 & 23.47 \\
\hline & \multicolumn{2}{|c|}{$18-25$} & 550 & 70.16 \\
\hline & \multicolumn{2}{|c|}{ over 25} & 50 & 6.37 \\
\hline \multirow{9}{*}{ Education level } & \multirow{4}{*}{ High school } & 9th grade & 40 & 5.10 \\
\hline & & 10th grade & 89 & 11.35 \\
\hline & & 11 th grade & 63 & 8.04 \\
\hline & & 12th grade & 56 & 7.14 \\
\hline & \multirow{3}{*}{$\begin{array}{l}\text { Undergraduate } \\
\text { students }\end{array}$} & 1st year & 65 & 8.29 \\
\hline & & 2nd year & 247 & 31.51 \\
\hline & & 3 rd year & 93 & 11.86 \\
\hline & \multirow{2}{*}{$\begin{array}{l}\text { Postgraduate students } \\
\text { (master's studies) }\end{array}$} & 1st year & 56 & 7.14 \\
\hline & & 2nd year & 75 & 9.57 \\
\hline \multirow{3}{*}{ Ability to browse the internet } & \multicolumn{2}{|c|}{ Yes } & 55 & 7.00 \\
\hline & \multicolumn{2}{|c|}{ No } & 661 & 84.31 \\
\hline & \multicolumn{2}{|c|}{ Doesn't know/undecided } & 68 & 8.69 \\
\hline \multirow{3}{*}{$\begin{array}{l}\text { Possession of a computer or of } \\
\text { similar equipment }\end{array}$} & \multicolumn{2}{|c|}{ Yes } & 629 & 80.22 \\
\hline & \multicolumn{2}{|c|}{ No } & 93 & 11.86 \\
\hline & \multicolumn{2}{|c|}{ Doesn't know/undecided } & 62 & 7.92 \\
\hline
\end{tabular}

Source: our own calculations based on Stata statistical analysis software.

In this study, the level of analysis also involved obtaining descriptive statistics. As shown in Table 4, the perception of the scales differs among groups.

Table 4. Descriptive statistics according to the educational level.

\begin{tabular}{ccccccc}
\hline \multirow{2}{*}{ Construct } & \multicolumn{2}{c}{ High School } & \multicolumn{2}{c}{ Undergraduate } & \multicolumn{2}{c}{ Postgraduate } \\
\cline { 2 - 6 } & Mean & Std. Error & Mean & Std. Error & Mean & Std. Error \\
\hline PHCA & 3.571 & 0.068 & 4.034 & 0.043 & 3.818 & 0.077 \\
ETC & 3.527 & 0.063 & 4.051 & 0.040 & 3.768 & 0.077 \\
EOE & 3.734 & 0.064 & 3.192 & 0.054 & 3.495 & 0.084 \\
AEI & 2.579 & 0.075 & 2.790 & 0.047 & 3.123 & 0.095 \\
TSA & 2.908 & 0.063 & 2.975 & 0.048 & 3.438 & 0.065 \\
\hline
\end{tabular}

This item is based on the five-point scale: $5=$ strongly agree, $4=$ agree, $3=$ don't know/uncertain, $2=$ disagree and 1 = strongly disagree; Source: our own calculations based on Stata statistical analysis software.

Table 5 presents descriptive statistics regarding the perceptions of university students and high school students considering the technology they have in order to access the online courses, as well as the ease of browsing the internet. According to the results, university students and high school students who declare that they are comfortable to browse the internet and have a computer or similar equipment allowing them to access the online courses will perceive online education as more effective. However, a regression equation is 
needed to show that this difference is also statistically significant in order to be able to test the hypotheses $\mathrm{H} 3$ and $\mathrm{H} 4$.

Table 5. Descriptive statistics according to groups of knowledge regarding the use of technology to access the courses.

\begin{tabular}{ccccc}
\hline & \multicolumn{2}{c}{$\begin{array}{c}\text { Technologically Challenged (Cannot Browse } \\
\text { the Internet Easily) }\end{array}$} & \multicolumn{2}{c}{$\begin{array}{c}\text { Has a Suitable Computer or } \\
\text { Similar Equipment }\end{array}$} \\
\hline \multirow{2}{*}{ Construct } & Yes & No & Yes & No \\
\cline { 2 - 5 } & Mean & Mean & Mean & Mean \\
\hline PHCA & 3.852 & 3.636 & 3.845 & 3.881 \\
ETC & 3.748 & 3.600 & 3.753 & 3.795 \\
EOE & 3.425 & 2.036 & 3.426 & 2.344 \\
AEI & 2.804 & 3.236 & 2.790 & 3.333 \\
TSA & 2.937 & 2.072 & 2.939 & 2.322 \\
\hline
\end{tabular}

This item is based on the five-point scale: 5 = strongly agree, $4=$ agree, 3 = don't know/uncertain, $2=$ disagree and 1 = strongly disagree. Source: our own calculations based on Stata statistical analysis software.

Table 6 shows the parallel correlations between the variables, which are generally weak, without a correlation above 0.411 . Even if there are some variables significantly correlated with each other, we can state that there are no factors preventing consistent results. This is also confirmed by the verification of the variation inflation values (VIF), which are lower than 10 .

Table 6. Variable testing and validation.

\begin{tabular}{|c|c|c|c|c|c|c|}
\hline & VIF & EOE & Age & Gender & $\begin{array}{l}\text { Ability to Browse the } \\
\text { Internet }\end{array}$ & $\begin{array}{c}\text { Possession of a Computer or of } \\
\text { Similar Equipment }\end{array}$ \\
\hline EOE & - & 1.000 & & & & \\
\hline Age & 2.090 & 0.048 & 1.000 & & & \\
\hline Gender & 1.083 & 0.120 * & 0.145 * & 1.000 & & \\
\hline Ability to browse the internet & 1.294 & $0.383 *$ & 0.071 & 0.066 & 1.000 & \\
\hline $\begin{array}{c}\text { Possession of a computer or of } \\
\text { similar equipment }\end{array}$ & 1.511 & $0.367 *$ & $0.100 *$ & 0.013 & 0.411 * & 1.000 \\
\hline
\end{tabular}

Note: ${ }^{*}$ indicate the fact that $p<0.05$. Source: our own calculations based on Stata statistical analysis software.

Table 7 shows the regression coefficients. The results of the equation show that university students and high school students who own a computer/laptop which allows them to access online courses perceive online courses as more effective than those who do not possess this technology which is vital in an online education environment. In addition, university students and high school students who are accustomed to the online communication, as well as those who declared themselves able to access online courses perceive online education as more effective than those who declared themselves new in online communication, or who have difficulties in accessing the internet. The significance level is in both cases 0.000 , which is very good. The results of the regression also show that women perceive online education as more effective, compared with men who perceive it as less effective. In addition, undergraduate students perceive online education as slightly less effective. 
Table 7. Variable testing and validation.

\begin{tabular}{|c|c|c|c|c|c|}
\hline EOE & $\beta$ & Err. Std. & $\mathbf{t}$ & $\mathbf{F}$ & Adj $R^{2}$ \\
\hline Age & $0.009(0.816)$ & 0.011 & 0.84 & \multirow{5}{*}{$49.09^{* * *}$} & \multirow{5}{*}{0.224} \\
\hline Gender & $\begin{array}{c}0.263^{* * *} \\
(0.001)\end{array}$ & 0.078 & 3.40 & & \\
\hline Ability to browse the internet & $\begin{array}{l}1.032 * * * \\
(0.000)\end{array}$ & 0.142 & 7.24 & & \\
\hline $\begin{array}{l}\text { Possession of a computer or of } \\
\text { similar equipment }\end{array}$ & $\begin{array}{l}0.859 * * * \\
(0.000)\end{array}$ & 0.119 & 7.20 & & \\
\hline cons & $\begin{array}{c}1.414^{* * *} \\
(0.000)\end{array}$ & 0.209 & 6.77 & & \\
\hline
\end{tabular}

Note: ${ }^{* * *}$ indicate the fact that $p<0.01$, respectively. Source: our own calculations based on Stata statistical analysis software.

4.2. Model of the Structural Equation of the Factors Influencing the Perception of University Students and High School Students of Online Education during the State of Emergency Caused by the COVID-19 Pandemic

After an analysis of the exploratory factors and a regression analysis, we proposed the research model (Figure 2), provided that the standardized loadings are at least 0.400 . Moreover, there were no loadings on several factors $(\beta>0.35)$. Thus, the next step indicates the estimated measurement model using the confirmatory factor analysis (CFA).

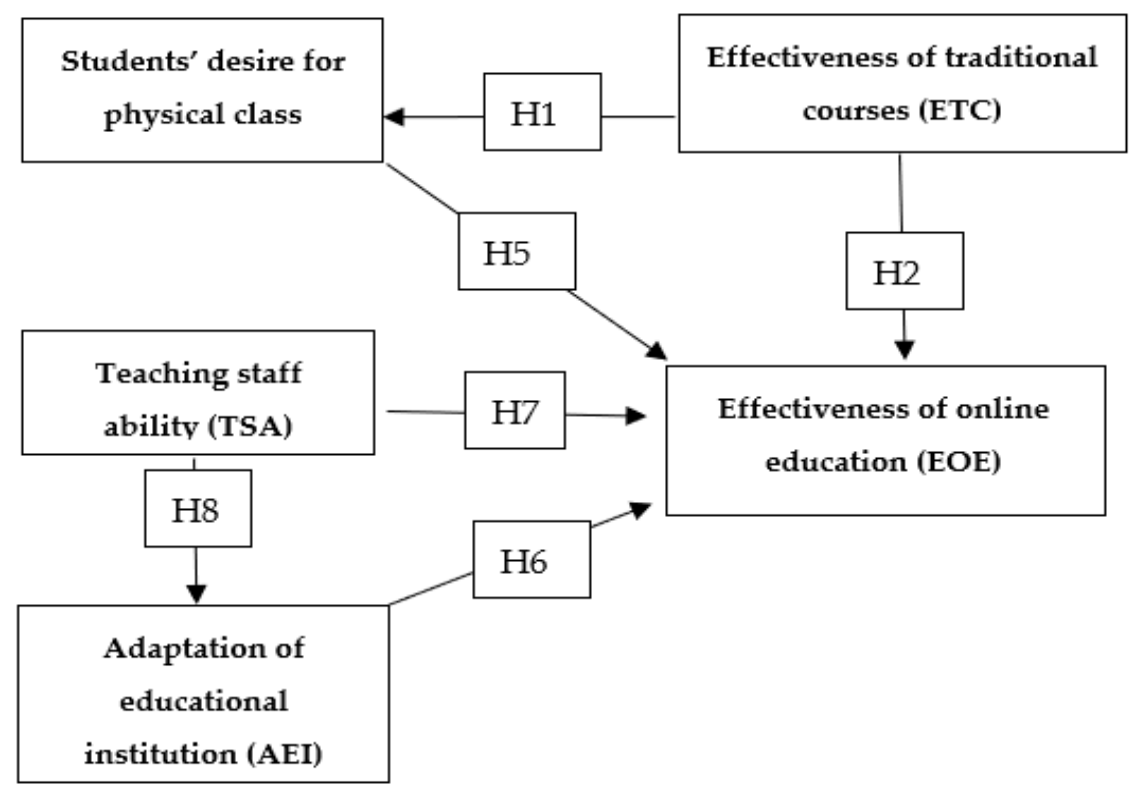

Figure 2. The structural model regarding effectiveness of online courses during the state of emergency caused by the COVID-19 pandemic.

We used several tests to evaluate the general model and to test hypotheses $\mathrm{H} 1, \mathrm{H} 2$, H5, H6, H7 and H8.

Goodness of fit measures were used to assess the overall structural model. For high school students $\mathrm{chi}^{2} / \mathrm{df}$ is $412,250 / 126$, RMSEA is 0.075, CFI is 0.890 , TLI is 0.877 , and SRMR is 0.083 . For undergraduate students, the fit indices are as follows: $\mathrm{chi}^{2} / \mathrm{df}$ is $432,772 / 126$, RMSEA is 0.077 , CFI is 0.907 , TLI is 0.887 and SRMR is 0.067 , and for postgraduate students $\mathrm{chi}^{2} / \mathrm{df}$ is $287,591 / 126$, RMSEA is 0.087 , CFI is 0.908 , TLI is 0.877 and SRMR is 0.083 . The study results and the general classification indices for the proposed model are presented according to the education level in Table 8. 
Table 8. Fit indices for the structural model.

\begin{tabular}{cccccc}
\hline \multirow{2}{*}{ Education Levels } & \multicolumn{5}{c}{ Fit Indices } \\
\cline { 2 - 6 } & $\mathbf{c h i}^{2} / \mathbf{d f}$ & RMSEA & CFI & TLI & SRMR \\
\hline High school & $412.250 / 126$ & 0.075 & 0.890 & 0.877 & 0.083 \\
\hline Undergraduate & $432.772 / 126$ & 0.077 & 0.907 & 0.887 & 0.067 \\
\hline Postgraduate & $287.591 / 126$ & 0.087 & 0.908 & 0.877 & 0.062 \\
\hline
\end{tabular}

Source: our own calculations based on Stata statistical analysis software.

The AVE is used to determine convergent validity. An average variance extracted (AVE) that is higher than 0.5 is preferred, but a value of 0.4 can be accepted, as Fornell and Larcker argued that if AVE is less than 0.5, but composite reliability is higher than 0.6, the convergent validity of the construct is still adequate [60] (see Appendices A-C for the standardized loadings and AVE results).

Based on the results, the structural model by education levels is shown in Figures 3-5, together with the standardized statistical results of the structural equation.

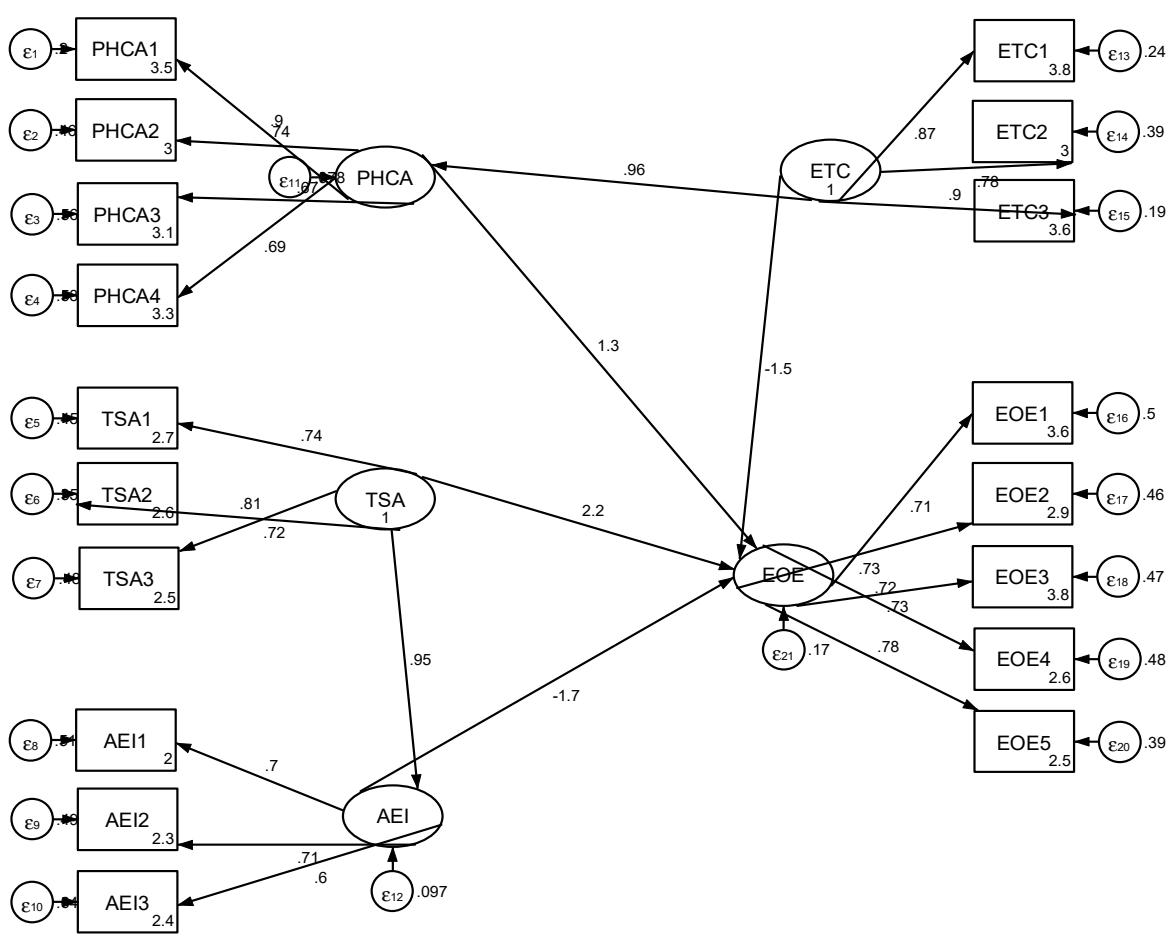

Figure 3. The structural model regarding effectiveness of online courses during the state of emergency caused by the COVID-19 pandemic for high school students. 


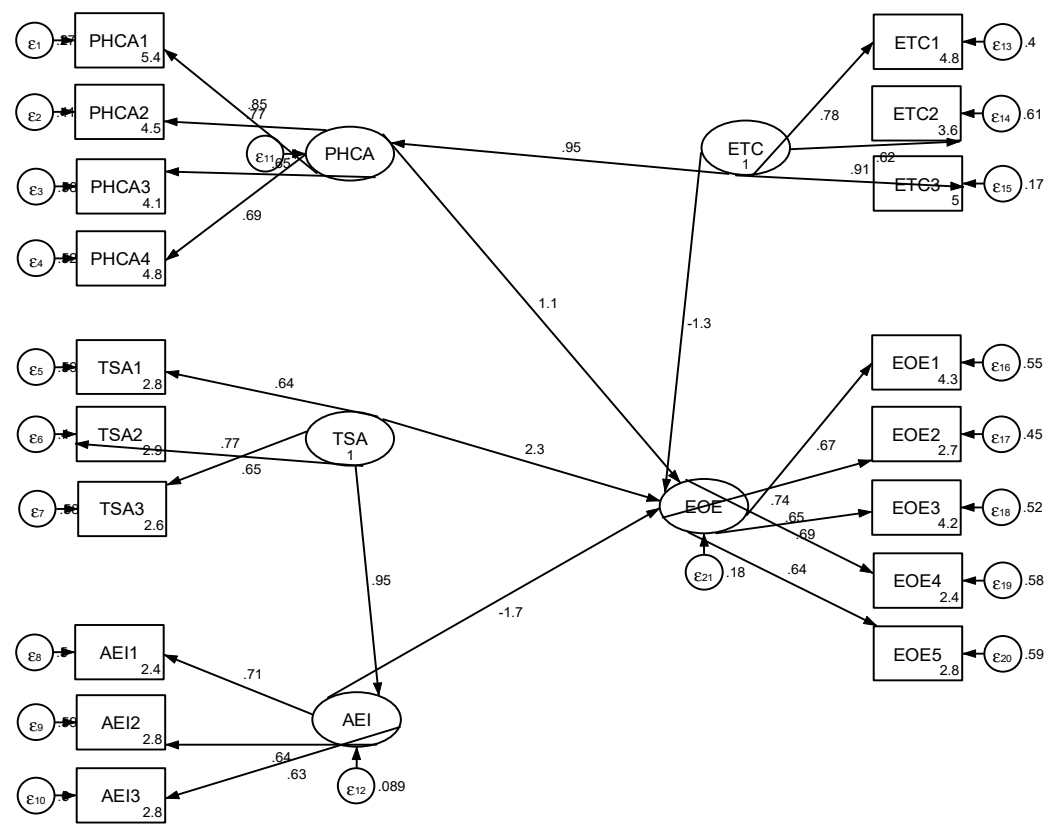

Figure 4. The structural model regarding effectiveness of online courses during the state of emergency caused by the COVID-19 pandemic for undergraduate students.

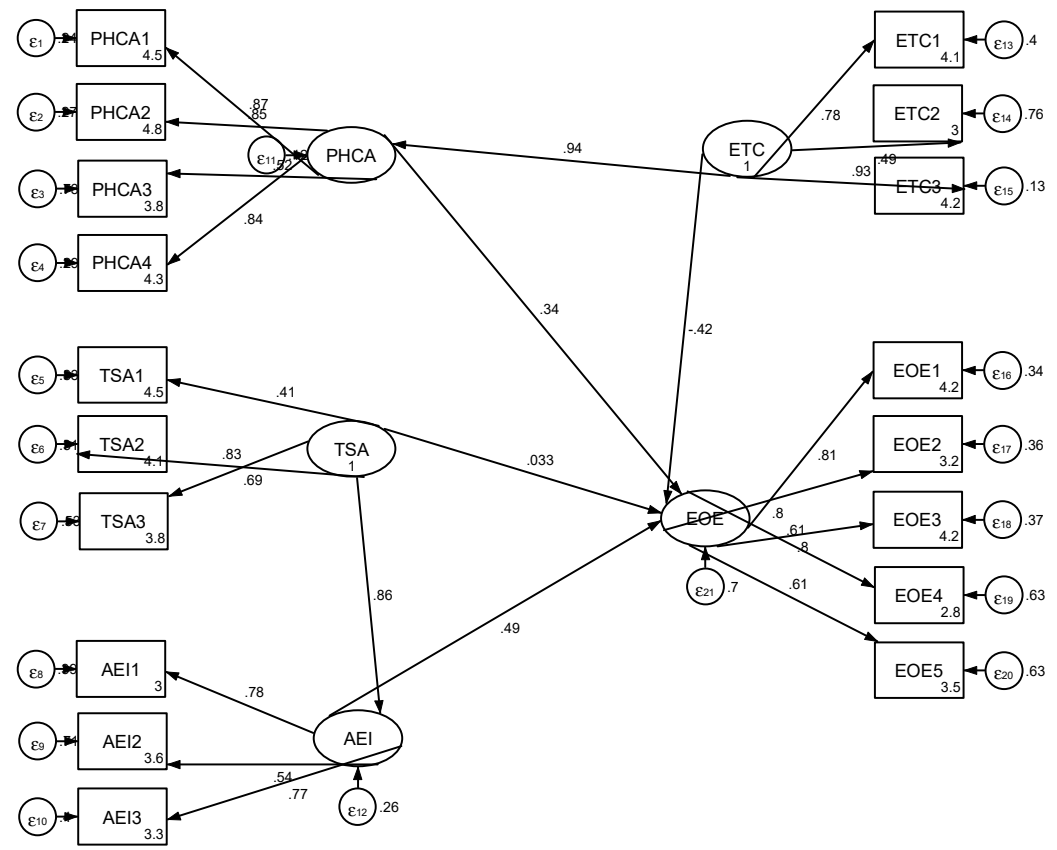

Figure 5. The structural model regarding effectiveness of online courses during the state of emergency caused by the COVID-19 pandemic for postgraduate students.

The structural model assessment helps to investigate the empirical data to confirm the hypotheses. Figure 1 presents the model studied. Figure 3 shows the relationships between variables for the sample containing the high school students. The findings confirm the significant effect $(\beta=-0.960 ; p=0.000)$ of the perception of effectiveness of traditional courses (ETC) on students' desire for physical class attendance (PHCA), of the perception of effectiveness of traditional courses (ETC) on the perception of effectiveness of online education (EOE), with $\beta$ of $-1.462, p=0.018$. Positive significant results also confirm the effect of PHCA on EOE ( $\beta=1.342, p=0.032)$, the effect of the perception of teaching staff ability (TSA) on the perception of effectiveness of online education (EOE) with a $\beta$ of 2.238 
$(p=0.090)$ and the effect of TSA on the adaptation of the educational institution (AEI), $\beta=0.950(p=0.000)$.

Moreover, from the results, the effect of AEI on EOE is not statistically significant $(\beta=-1.709, p=0.198)$.

Figure 4 shows the relationships between variables for the sample containing the undergraduate students. The findings confirm the significant effect $(\beta=-0.948 ; p=0.000)$ of the perception of effectiveness of traditional courses (ETC) on students' desire for physical class attendance (PHCA), of the perception of effectiveness of traditional courses (ETC) on the perception of effectiveness of online education (EOE), with $\beta$ of $-1.298, p=0.002$. Positive significant results also confirm the effect of PHCA on EOE $(\beta=1.088, p=0.011)$ and the effect of TSA on the adaptation of the educational institution (AEI), $\beta=0.954$ $(p=0.000)$.

Moreover, from the results, the effect of AEI on EOE and on TSA on EOE are not statistically significant.

Figure 5 shows the relationships between variables for the sample containing the postgraduate students. The findings confirm the significant effect $(\beta=-0.938 ; p=0.000)$ of the perception of effectiveness of traditional courses (ETC) on students' desire for physical class attendance (PHCA). The only other statistically significant relationship is represented by the effect of TSA on AEI ( $\beta=0.858, p=0.000)$.

Moreover, from the results, the effect of ETC on EOE, PHCA on EOE, AEI on EOE and on TSA on EOE are not statistically significant.

Standardized regression coefficients show that hypotheses $\mathrm{H} 1$ and $\mathrm{H} 8$ are confirmed for all groups of students, hypotheses $\mathrm{H} 2, \mathrm{H} 5$ and $\mathrm{H} 7$ are partially confirmed, while hypothesis H6 cannot be confirmed. The coefficients are shown in Table 9.

Table 9. Coefficients (SEM output).

\begin{tabular}{|c|c|c|c|c|c|c|}
\hline & \multicolumn{6}{|c|}{ Parameter Estimations } \\
\hline & \multicolumn{3}{|c|}{ Coefficient } & \multicolumn{3}{|c|}{ Is the Hypothesis Supported? } \\
\hline & $\begin{array}{l}\text { High School } \\
\text { Students }\end{array}$ & $\begin{array}{l}\text { Undergraduate } \\
\text { Students }\end{array}$ & $\begin{array}{l}\text { Postgraduate } \\
\text { Students }\end{array}$ & $\begin{array}{l}\text { High School } \\
\text { Students }\end{array}$ & $\begin{array}{l}\text { Undergraduate } \\
\text { Students }\end{array}$ & $\begin{array}{l}\text { Postgraduate } \\
\text { Students }\end{array}$ \\
\hline H1:ETC $\rightarrow$ PHCA & $\begin{array}{l}0.960 * * * \\
(0.000)\end{array}$ & $\begin{array}{l}0.948^{* * *} \\
(0.000)\end{array}$ & $\begin{array}{l}0.938^{* * *} \\
(0.000)\end{array}$ & YES & YES & YES \\
\hline $\mathrm{H} 2: \mathrm{ETC} \rightarrow \mathrm{EOE}$ & $\begin{array}{c}-1.462^{* *} \\
(0.018)\end{array}$ & $\begin{array}{c}-1.298^{* * *} \\
(0.002)\end{array}$ & $\begin{array}{l}-0.422 \\
(0.366)\end{array}$ & YES & YES & $\mathrm{NO}$ \\
\hline H5:PHCA $\rightarrow$ EOE & $\begin{array}{l}1.342 \text { ** } \\
(0.032)\end{array}$ & $\begin{array}{l}1.088^{* *} \\
(0.011)\end{array}$ & $\begin{array}{c}0.337 \\
(0.470)\end{array}$ & YES & YES & NO \\
\hline H6:AEI $\rightarrow$ EOE & $\begin{array}{l}-1.709 \\
(0.198)\end{array}$ & $\begin{array}{l}-1.737 \\
(0.216)\end{array}$ & $\begin{array}{c}0.493 \\
(0.101)\end{array}$ & $\mathrm{NO}$ & $\mathrm{NO}$ & $\mathrm{NO}$ \\
\hline H7:TSA $\rightarrow$ EOE & $2.238 *(0.090)$ & $\begin{array}{c}2.264 \\
(0.105) \\
\end{array}$ & $\begin{array}{c}0.032 \\
(0.915) \\
\end{array}$ & YES & $\mathrm{NO}$ & $\mathrm{NO}$ \\
\hline H8:TSA $\rightarrow$ AEI & $\begin{array}{c}0.950 * * * \\
(0.000)\end{array}$ & $\begin{array}{c}0.954^{* * *} \\
(0.000)\end{array}$ & $\begin{array}{c}0.858^{* * *} \\
(0.000)\end{array}$ & YES & YES & YES \\
\hline
\end{tabular}

Note: ${ }^{*} * *, * * *$ indicate the fact that $p<0.10, p<0.05, p<0.01$, respectively. Source: our own calculations using Stata statistical analysis software.

\section{Discussion}

Theoretical and empirical approaches investigate online education and the perception of university students and/or high school students of online education. This study addresses an important and topical issue.

In this study we used multiple linear regression models and structural analysis (SEM), which tested the following hypotheses: 
Hypothesis 1 (H1). The perception of the effectiveness of face-to-face courses will influence students' desire for physical class attendance.

This hypothesis was tested with the help of the structural model, and the results show that there is a statistically significant positive relationship between the perception of the effectiveness of face-to-face courses and students' desire for physical class attendance. This is available for all categories of students analyzed, with a standardized coefficient of 0.960 for high school students, 0.948 for undergraduate students, and 0.938 for postgraduate students. The hypothesis is thus confirmed.

Hypothesis 2 (H2). The perception of the effectiveness of face-to-face courses will negatively influence the perception of the effectiveness of online courses.

This hypothesis was tested with the help of the structural model, and the results show that there is a negative relationship between the perception of the effectiveness of face-to-face courses and the perception of effectiveness of online courses. However, this relationship is statistically significant $(p<0.05)$ only for high school students and for undergraduate students. However, the results show a statistically insignificant relationship for postgraduate students, with a $p$-Value of 0.366 . The hypothesis is only partially confirmed.

Hypothesis 3 (H3). The students who do not possess the technology needed for easy access to online courses will perceive them as ineffective compared with the students who possess the technology.

This hypothesis was tested with the help of a regression equation. The regression coefficient is 0.859 and it is statistically significant. Therefore, we can see that respondents who own a computer, or similar good-quality equipment granting them access to online courses, perceive these courses as more effective. The hypothesis confirms research results suggesting that mobile devices and good internet access can lead to improvements by stimulating and involving students in the educational process [20,21].

Hypothesis 4 (H4). The students who can browse the internet easily will perceive the effectiveness of online courses differently compared with the other students.

This hypothesis was tested with the help of a regression equation. The results show that the respondents who said that they could easily browse the internet will perceive online courses as more effective. The regression coefficient is 1.032 and it is statistically significant. Consequently, hypothesis $\mathrm{H} 4$ is confirmed.

Hypothesis 5 (H5). Students' desire for physical class attendance will generate the perception of ineffectiveness of online courses.

This hypothesis was tested with the help of the structural model, and the results show that there is a statistically significant reverse relationship between the students' desire for physical class attendance and the perception of the effectiveness of online courses. Nevertheless, this is less true for the postgraduate students, where the relationship is not statistically significant. The hypothesis is thus only partially confirmed.

Hypothesis 6 (H6). The capacity of educational institutions to manage online courses will have a positive effect on the students' perception of the effectiveness of online courses.

This hypothesis was tested with the help of the structural model, and the results show that this relationship is statistically insignificant for all groups of students. This may suggest that the trust in educational institutions does not manifest itself within online courses, where the trust in teachers/professors is more important and where we can say that there is a disconnection between high school students and university students on the one hand, and the educational institution on the other hand. Consequently, we cannot state that Hypothesis $\mathrm{H6}$ is confirmed, because the results are not statistically significant for any of the categories analyzed. 
Hypothesis 7 (H7). The capacity of the teaching staff to be more lenient will have a positive effect on the perception of the effectiveness of online courses.

This hypothesis was tested with the help of the structural model, and the results show that there is a statistically significant positive relationship between the capacity of the teaching staff to be more lenient and the perception of the effectiveness of online courses for the high school students group. However, this is not true for some categories of students analyzed. For the groups of undergraduate and postgraduate students, this relationship is statistically insignificant. Hypothesis H7 is confirmed only for the group of high school students.

Hypothesis $\mathbf{8}$ (H8). The perception of the ability of teaching staff to manage online courses will have a positive effect on the perception of the adaptation of the educational institution to online education.

This hypothesis was tested with the help of the structural model, and the results show that there is a statistically significant positive relationship between the perception regarding teaching staff's ability to manage online courses and the perception regarding the adaptation of educational institution to online education. This is true for all categories of students analyzed. Hypothesis H8 is thus confirmed.

This study aimed to explore the perceptions of university students and high school students regarding online education during the state of emergency caused by the COVID19 pandemic. The results confirmed previous research such as Bali and Liu [5] and Platt, Raile and Yu [6], suggesting that students have clear perceptions of online education and of the components they consider necessary for their success in this environment.

Our results show that the educational level does not necessarily have an influence on perceptions and attitudes regarding online education. However, the material level has a positive effect (expressed by the existence or not of a technology allowing them to participate in online courses), in terms of familiarity with online communication and skills in using a computer, a tablet or a laptop.

\section{Conclusions}

The coronavirus pandemic differs from one country to another, but for the educational environment it is extremely important to take measures aimed at protecting young students and, implicitly, their health, such as: providing students with equal and non-discriminatory education opportunities, equal training for all students, protection of students with various vulnerabilities, and the use of opportunities regarding the possibilities of reorganization of the instructional/educational process. A priority of the reorganization of the education system is to build teams made of students, teaching staff and people outside the education system in order to identify responses to current emerging requirements [10,57].

The distance learning model has attracted new experiences which require the transfer of activity planning from the traditional format to the online format. This change is expected to be temporary, based on the circumstances generated by the COVID-19 crisis. Once the crisis ends, the format of instructional/educational activities will return to its original state. The objective of the current circumstances is to allow temporary access to the contents of compulsory training programs for the current year of study and not to create a new education system [1].

Author Contributions: Conceptualization, G.I.B., V.N., A.A. and G.B.; methodology, G.I.B. and A.A.; software, A.A.; validation, G.I.B. and A.A.; formal analysis, G.I.B., V.N., A.A. and G.B.; investigation, A.A.; resources, G.I.B., V.N., A.A. and G.B.; data curation, V.N., A.A. and G.B.; writing-original draft preparation, G.I.B., V.N., A.A. and G.B.; writing-review and editing, G.I.B., V.N., A.A. and G.B.; visualization, G.I.B., V.N., A.A. and G.B.; supervision, G.I.B., V.N., A.A. and G.B.; project administration, G.I.B., V.N., A.A. and G.B.; funding acquisition, G.I.B., V.N., A.A. and G.B. All authors have read and agreed to the published version of the manuscript. 
Funding: This research received no external funding.

Institutional Review Board Statement: Not applicable.

Informed Consent Statement: Not applicable.

Data Availability Statement: Not applicable.

Conflicts of Interest: The authors declare no conflict of interest.

\section{Appendix A}

Table A1. Variable validity testing (structural model for the group of high school students).

\begin{tabular}{cccc}
\hline Items & Question & Loading (std.) & AVE \\
\hline \multirow{3}{*}{ PHCA } & PHCA1. & 0.9 & \\
& PHCA2. & 0.74 & 0.57 \\
& PHCA3. & 0.67 & \\
ETC & PHCA4. & 0.69 & 0.72 \\
& ETC1. & 0.87 & \\
\hline \multirow{2}{*}{ EOE } & ETC2. & 0.78 & \multirow{2}{*}{0.54} \\
& ETC3. & 0.9 & \\
& EOE1. & 0.71 & \\
& EOE2. & 0.73 & 0.45 \\
AEI & EOE3. & 0.72 & \\
& EOE4. & 0.73 & \\
& EOE5. & 0.78 & 0.57 \\
\hline \multirow{2}{*}{ TSA } & AEI1. & 0.7 & \\
& AEI2. & 0.71 & \\
\hline
\end{tabular}

Source: authors' elaboration using Stata statistical analysis software.

\section{Appendix B}

Table A2. Variable validity testing (structural model for the group of undergraduate students).

\begin{tabular}{|c|c|c|c|}
\hline Items & Question & Loading (std.) & AVE \\
\hline \multirow{4}{*}{ PHCA } & PHCA1. & 0.85 & \multirow{4}{*}{0.55} \\
\hline & PHCA2. & 0.77 & \\
\hline & PHCA3. & 0.65 & \\
\hline & PHCA4. & 0.69 & \\
\hline \multirow{3}{*}{ ETC } & ETC1. & 0.78 & \multirow{3}{*}{0.6} \\
\hline & ETC2. & 0.62 & \\
\hline & ETC3. & 0.91 & \\
\hline \multirow{5}{*}{ EOE } & EOE1. & 0.67 & \multirow{5}{*}{0.46} \\
\hline & EOE2. & 0.74 & \\
\hline & EOE3. & 0.65 & \\
\hline & EOE4. & 0.69 & \\
\hline & EOE5. & 0.64 & \\
\hline \multirow{3}{*}{ AEI } & AEI1. & 0.71 & \multirow{3}{*}{0.44} \\
\hline & AEI2. & 0.64 & \\
\hline & AEI3. & 0.63 & \\
\hline \multirow{3}{*}{ TSA } & TSA1. & 0.64 & \multirow{3}{*}{0.47} \\
\hline & TSA2. & 0.77 & \\
\hline & TSA3. & 0.65 & \\
\hline
\end{tabular}




\section{Appendix C}

Table A3. Variable validity testing (structural model for the group of postgraduate students).

\begin{tabular}{cccc}
\hline Items & Question & Loading (std.) & AVE \\
\hline \multirow{3}{*}{ PHCA } & PHCA1. & 0.87 & 0.61 \\
& PHCA2. & 0.85 & \\
& PHCA3. & 0.52 & \multirow{2}{*}{0.57} \\
ETC & PHCA4. & 0.84 & \\
& ETC1. & 0.78 & \\
& ETC2. & 0.49 & 0.54 \\
EOE & ETC3. & 0.93 & \\
& EOE1. & 0.81 & \multirow{2}{*}{0.5} \\
& EOE2. & 0.8 & \\
\hline \multirow{2}{*}{ AEI } & EOE3. & 0.61 & 0.8 \\
& EOE4. & 0.61 & 0.45 \\
\hline \multirow{2}{*}{ TSA } & EOE5. & 0.78 & \\
& AEI1. & 0.54 & \\
\hline
\end{tabular}

Source: authors' elaboration using Stata statistical analysis software.

\section{References}

1. Hodges, C.; Moore, S.; Lockee, B.; Trust, T.; Bond, A. The Difference between Emergency Remote Teaching and Online Learning, Why IT Matters to Higher Education. Available online: https://er.educause.edu/articles/2020/3/the-difference-betweenemergency-remote-teaching-and-online-learning (accessed on 12 July 2020).

2. Li, C.; Lalani, F. The COVID-19 Pandemic Has Changed Education Forever. This Is How. Available online: https://www. weforum.org/agenda/2020/04/coronavirus-education-global-covid19-online-digital-learning/ (accessed on 12 July 2020).

3. UNESCO. COVID-19 Impact on Education, Education: From Disruption to Recovery, COVID-19. Available online: https: / / en.unesco.org/covid19/educationresponse (accessed on 12 July 2020).

4. Bentley, K. Hybrid Learning Goes Mainstream amid Response to COVID-19. Available online: https://www.govtech.com/ education/k-12/hybrid-learning-goes-mainstream-amid-response-to-covid-19.html (accessed on 12 July 2020).

5. Bali, S.; Liu, M. Students' perceptions toward online learning and face-to-face learning courses. J. Phys. Conf. Ser. 2018, 1108, 012094. [CrossRef]

6. Platt, C.A.; Raile, A.; Yu, N. Virtually the same? Student perceptions of the equivalence of online classes vs. face-to-face classes Merlot J. Online Learn. Teach. 2014, 10, 489-494.

7. The World Bank. World Bank Education and COVID-19. Available online: https://www.worldbank.org/en/data/interactive/20 20/03/24/world-bank-education-and-covid-19 (accessed on 1 July 2020).

8. UNICEF. Sondaj U-Report Privind Școala Online. O Treime din Elevii Români Nu Sunt Mulțumiți de Școala Online și Nu Urmează Cursurile Prin Intermediul Platformelor Virtuale. UNICEF România. Available online: https://www.unicef.org/ romania/ro/pove\%C8\%99ti/sondaj-u-report-privind-\%C8\%99coala-online (accessed on 12 July 2020).

9. Ciobanu, C.L.; Ciobanu, N.M. E-learning Security Vulnerabilities. Procedia Soc. Behav. Sci. 2012, 46, 2297-2301. [CrossRef]

10. UNESCO. COVID-19 and Higher Education: Today and Tomorrow. Impact Analysis, Policy Responses and Recommendations. 2020. Available online: http:/ / www.iesalc.unesco.org/en/wp-content/uploads/2020/04/COVID-19-EN-090420-2.pdf (accessed on 2 July 2020).

11. Koehler, M.J.; Mishra, P.; Hershey, K.; Peruski, L. With a little help from your students: A new model for faculty development and online course design. J. Technol. Teach. Educ. 2004, 12, 25-55.

12. Ocak, M What We Learned about Distance Education during Covid-19? EPALE-Electronic Platform for Adult Learning in Europe. 2020. Available online: https://epale.ec.europa.eu/en/blog/what-we-learned-about-distance-education-during-covid-19 (accessed on 12 July 2020).

13. Fortune, M.; Spielman, M.; Pangelinan, D. Students' perceptions of online or face-to-face learning and social media in hospitality, recreation and tourism. Merlot J. Online Learn. Teach. 2011, 7, 1-16.

14. Arkorful, V.; Abaidoo, N. The role of e-learning, advantages and disadvantages of its adoption in higher education. Int. J. Educ. Res. 2014, 2, 397-410. 
15. Healy, S.; Block, M.; Judge, J. Adapted physical educators' perceptions of advantages and disadvantages of online teacher development. Palaest. Sagamore J. 2014, 28, 4.

16. UNICEF. UNICEF și Microsoft Lansează o Platformă Educațională Globală Pentru a Contribui la Gestionarea Crizei din Educație Provocată de COVID-19. Available online: https: / / www.unicef.org / romania / ro / topics / covid-19?items_per_page=10\&page=8 (accessed on 12 July 2020).

17. Ghaderizefreh, S.; Hoover, M.L. Student satisfaction with online learning in a blended course. Int. J. Digit. Soc. 2018, 9, 3. [CrossRef]

18. Apuke, O.D.; Iyendo, T.O. University students usage of the internet resources for research and learning: Forms of access and perceptions of utility. Heliyon 2018, 4, e01052. [CrossRef]

19. Gan, C.; Li, H. Understanding the effects of gratifications on the continuance intention to use WeChat in China: A perspective on uses and gratifications. Comput. Hum. Behav. 2018, 78, 306-315. [CrossRef]

20. Ramirez, M.; Gordy, C. Tips for Students to Prepare for Online Learning, Online and Distance Education News. Available online: https:/ / online-distance.ncsu.edu/tips-for-students-to-prepare-for-online-learning/ (accessed on 12 July 2020).

21. Santos, H.; Batista, J.; Marques, R.P. Digital transformation in higher education: The use of communication technologies by students. Procedia Comput. Sci. 2019, 164, 123-130. [CrossRef]

22. Dorn, E.; Hancock, B.; Sarakatsannis, J.; Viruleg, E. COVID-19 and Student Learning in the United States: The Hurt Could Last a Lifetime. Available online: https:/ / www.mckinsey.com/industries/public-sector/our-insights/covid-19-and-student-learningin-the-united-states-the-hurt-could-last-a-lifetime\# (accessed on 12 July 2020).

23. Farrington, D. The Consequences of COVID-19 on the Education System: The Legal Perspective. Available online: https://www. coe.int/en/web/education/article-the-consequences-of-covid-19-on-the-education-system-the-legal-perspective (accessed on 12 July 2020).

24. UNESCO. Distance Learning Solutions, More on UNESCO's COVID-19 Education Response. Available online: https: / en.unesco. org/covid19/educationresponse/solutions (accessed on 12 July 2020).

25. Peticilă, M. Părinții, Obligați să le Asigure Copiilor Calculator/Laptop/Tabletă / Telefon Smart cu Internet Pentru A Participa la Cursuri Online, A Stabilit Ministerul Educației. Elevii, Obligați să Participe la Orele pe Net Stabilite de Școală. Available online: https:/ / www.edupedu.ro/parintii-obligati-sa-le-asigure-copiilor-calculator-laptop-tableta-telefon-smart-cu-internetpentru-a-participa-la-cursurile-online-a-stabilit-ministerul-educatiei-elevii-obligati-sa-participe-la/ (accessed on 12 July 2020).

26. Kebritchi, M.; Lipschuetz, A.; Santiague, L. Issues and challenges for teaching successful online courses in higher education: A Literature review. J. Educ. Technol. Syst. 2017, 46, 4-29. [CrossRef]

27. Hung, M.; Chou, C.; Chen, C.; Own, Z. Learner readiness for online learning: Scale development and student perceptions. Comput. Educ. 2010, 55, 1080-1090. [CrossRef]

28. Basilaia, G.; Kvavadze, D. Transition to online education in schools during a SARS-CoV-2 Coronavirus (COVID-19) pandemic in Georgia. Pedagog. Res. 2020, 5, 1-9. [CrossRef]

29. Neil, K. Using Social Distance to Strengthen University Communities. Available online: https:/ / www.universityworldnews com/post.php?story=20200504082923788 (accessed on 23 July 2020).

30. Reimers, F.; Schleicher, A.; Saavedra, J.; Tuominen, S. Supporting The Continuation of Teaching and Learning during the COVID-19 Pandemic Annotated Resources for Online Learning. Available online: http:/ /www.oecd.org/education/Supportingthe-continuation-of-teaching-and-learning-during-the-COVID-19-pandemic.pdf (accessed on 2 July 2020).

31. Bender, L. Key Messages and Actions for COVID-19 Prevention and Control in Schools. Available online: https: / / www.who.int/docs/default-source / coronaviruse/ key-messages-and-actions-for-covid-19-prevention-and-control-inschools-march-2020.pdf?sfvrsn=baf81d52_4\&gclid=Cj0KCQjw6uT4BRD5ARIsADwJQ197uVW8uB1-D26t0LB9t-P3ENYMnm_Cbyk6fMh9mf2yZ1s-0Dxlt4aAikNEALw_wcB (accessed on 12 July 2020).

32. Castaneda, D.; Rentz, S. The Power of Discussion: Activating Learning Online (And in Person). Available online: https: / / elearningindustry.com/social-interaction-in-online-courses-discussion-activating-learning (accessed on 30 July 2020).

33. Watts, L. Synchronous and asynchronous communication in distance learning: A review of the literature. Q. Rev. Distance Educ. 2016, 17, 23-32.

34. Wazzan, M. 15 min of Fame: Online Learning in the Coronavirus Era. Available online: https://www.al-fanarmedia.org/2020/0 4/15-minutes-of-fame-online-learning-in-the-coronavirus-era/ (accessed on 2 July 2020).

35. Hobfoll, S.E.; Cameron, R.P.; Chapman, H.A.; Gallagher, R.W. Social Support and Social Coping in Couples. In Handbook of Social Support and the Family; The Springer Series on Stress and Coping; Pierce, G.R., Sarason, B.R., Sarason, I.G., Eds.; Springer: Boston, MA, USA, 1996.

36. Mishra, S. Social networks, social capital, social support and academic success in higher education: A systematic review with a special focus on 'underrepresented' students. Educ. Res. Rev. 2020, 29, 100307. [CrossRef]

37. Darling-Hammond, L.; Cook-Harvey, M. Educating the Whole Child: Improving School Climate to Support Student Success. Available online: https://learningpolicyinstitute.org/sites/default/files/product-files/Educating_Whole_Child_REPORT.pdf (accessed on 12 July 2020).

38. Mather, M.; Sarkans, A. Student perceptions of online and face-to-face learning. Int. J. Curric. Instr. 2018, 10, 61-76.

39. Alsaaty, F.; Carter, E.; Abrahams, D.; Alshameri, F. Traditional versus online learning in institutions of higher education: Minority business students' perceptions. Bus. Manag. Res. 2016, 5. [CrossRef] 
40. Popescu, A.L. Misiune Imposibilă în Educație: Cum Muți Peste Noapte Școala în Online. Available online: https:/ /romania. europalibera.org/a/misiune-imposibila-educatie-cum-muti-peste-noapte-scoala-online/30592445.html (accessed on 12 July 2020).

41. Gabor, A. Schools Aren't Ready for Online Learning. Available online: https://www.bloombergquint.com/gadfly/coronavirusshutdowns-highlight-weakness-of-online-u-s-schooling (accessed on 30 July 2020).

42. Anderson, D.; Imdieke, S.; Standerford, N.S. Feedback please: Studying self in the online classroom. Int. J. Instr. 2011, 4, 3-15.

43. Manea, R. Ce ar putea fi învățarea online în lipsa școlii. Available online: https://www.edupedu.ro/ce-ar-putea-fi-invatareaonline-in-lipsa-scolii-ruxandra-manea-antreprenor-in-educatie/ (accessed on 12 July 2020).

44. Vu, C.T.; Hoang, A.D.; Than, V.Q.; Nguyen, M.T.; Dinh, V.H.; Le, Q.A.T.; Le, T.T.T.; Pham, H.H.; Nguyen, Y.C. Dataset of Vietnamese teachers' perspectives and perceived support during the COVID-19 pandemic. Data. Brief. 2020, $31,105788$. [CrossRef] [PubMed]

45. Hardy, L. 5 Skills That Online Teachers Are Constantly Developing, eLearning Best Practices. Available online: https:// elearningindustry.com/5-skills-online-teachers-developing (accessed on 12 July 2020).

46. Bao, W. COVID -19 and online teaching in higher education: A case study of Peking University. Hum. Behav. Emerg. Technol. 2020, 2. [CrossRef]

47. Cooper, S. 5 Strategies To Improve Your Online Teaching. eLearning Best Practices. Available online: https:// elearningindustry. com/5-strategies-improve-your-online-teaching (accessed on 12 July 2020).

48. Niess, M.; Gillow-Wiles, H. Developing asynchronous online courses: Key instructional strategies in a social metacognitive constructivist learning trajectory. Distance. Educ. 2013, 27. Available online: http:/ /www.ijede.ca/index.php/jde/article/view/ $831 / 1473$ (accessed on 9 January 2021).

49. Duncan, L. The Transition from Face-to-Face to Online Learning: Maintaining an Engaging Experience. Available online: https:/ / community.brightspace.com/s/article/The-Transition-from-Face-to-Face-to-Online-Learning-Maintaining-anEngaging-Experience (accessed on 12 July 2020).

50. Cross, L.K. Graduate student perceptions of online advising. NACADA J. 2018, 38, 72-80. [CrossRef]

51. Song, H.; Kim, J.; Luo, W. Teacher-student relationship in online classes: A role of teacher self-disclosure. Comput. Hum. Behav. 2016, 54, 436-443. [CrossRef]

52. The Romanian Ministry of Education. Instrucțiunea Pentru Crearea și/sau întărirea Capacității Sistemului de învățământ Preuniversitar prin învățare on-line, din 21.04.2020, Text Publicat în Monitorul Oficial, Partea I nr. In 331 din 23 aprilie 2020. În vigoare de la 23 aprilie 2020. Available online: https:/ / lege5.ro/Gratuit/gm3dqmrzhe2a/instructiunea-pentru-crearea-si-sauintarirea-capacitatii-sistemului-de-invatamant-preuniversitar-prin-invatare-on-line-din-21042020 (accessed on 2 July 2020).

53. Educred Un Portal în Sprijinul Cadrelor Didactice. Available online: https:/ / digital.educred.ro/home (accessed on 12 July 2020).

54. Treacy, B. Developing Strategies for Online Teaching and Learning, Professional Education. Available online: https://www.gse. harvard.edu/ppe/program/developing-strategies-online-teaching-and-learning (accessed on 12 July 2020).

55. Langa, C.; Tudor, L.S.; Stan, M.M.; Bulgaru, I. Educația Față cu Provocările Unei Situații Excepționale. Available online: https: //www.upit.ro/ro/upit-pentru-comunitate/educatia-fata-cu-provocarile-unei-situatii-exceptionale (accessed on 12 July 2020).

56. Roșculeț, G. Contextul Învățării în Vreme De Izolare. Available online: https:/ / oradenet.salvaticopiii.ro/blog/contextul-invatariiin-vreme-de-izolare-2/ (accessed on 12 July 2020).

57. The Romanian Ministry of Education. Consultare Publică Lansată de Comisia Europeană Privind Revizuirea Planului De Acțiune Pentru Educația Digitală. Available online: https://www.edu.ro/consultare-public\%7B/fontencoding\%7BT5\%7D/selectfont\% 7B/abreve\%7D\%7D-lansat\%7B/fontencoding\%7BT5\%7D/selectfont\%7B/abreve\%7D\%7D-de-comisia-european\%7B (accessed on 12 July 2020).

58. Field, A. Discovering Statistics Using SPSS; Sage Publications Ltd.: London, UK, 2009; ISBN 978-1-84787-906-6.

59. Comrey, A.; Lee, H. A First Course in Factor Analysis; Erlbaum: Hillsdale, NJ, USA, 1992; ISBN 0-8058-1062-5.

60. Fornell, C.; Larcker, D. Evaluating Structural Equation Models with Unobservable Variables and Measurement Error. J. Mark. Res. 1981, 18, 39-50. [CrossRef] 